\title{
Daniels eta Worthingham-en muskulu-probak. Eskuzko miaketarako eta funtzionamendua balioesteko teknikak
}

\author{
Daniels and Worthingham's muscle testing. Techniques of manual examination \\ and performance testing
}

Iker Villanueva Ruiz

Fisioterapia Saila. Psikologia eta Hezkuntza Fakultatea. Deustuko Unibertsitatea

iker.villanueva@deusto.es

\section{Laburpena}

Artikulu hau Daniels eta Worthingham-en muskulu-probak. Eskuzko miaketarako eta funtzionamendua balioesteko teknikak liburuaren aurkezpen bat da eta bertan liburuaren edukiak deskribatzen dira.

Gako-hitzak: fisioterapia, muskulua, diagnostikoa

\section{Abstract}

This article is a presentation of the book Daniels and Worthingham's muscle testing. Techniques of manual examination and performance testing, where the contents of the book are described.

Keywords: physiotherapy, muscle, diagnosis

\section{Sarrera}

Hirurogeita hamar urte inguru igaro dira Lucille Daniels eta Catherine Worthingham-ek Muscle Testing. Techniques of Manual Examination liburua argitaratu zutenetik eta, moldaketa eta hainbat argitaraldiri esker, aberastuz joan da beraien lana. Jatorriz ingelesez idatzita dago eta bere edizioetan zehar hainbat hizkuntzatara itzuli izan da, besteak beste, gaztelaniara eta frantsesera.

Bederatzigarren argitaraldiaren itzulpena den liburu honek berrikuntzak ditu, aurrekoekin alderatuz: hainbat adinetako pazienteen gaitasun funtzionalari buruzko kapitulu berria du, baita eskuzko proba muskularren adierazgarritasunari, mugei eta alternatibei buruzko atal gehigarria ere. Horrez gain, klinikarekin harreman estuagoa duten atalak ere baditu, hala nola kasu klinikoak eta aurkezpen kliniko desberdinetan erabiltzeko muskulu-probak.

\section{Edukiak}

Indar muskularraren miaketarako gida bat da, fisioterapiaren eguneroko praktika klinikoan oso erabilia den prozedura, eta gainerako osasun-jakintzagaietan ere erabilgarria. Fisioterapiadiagnostikorako ezinbestekoa den muskuluen miaketarako probak azaltzen ditu, eskuekin egindakoak.

Proba horiek muskuluak ezik giltzaduren mugimenduak aztertzen dituzte, probak eta mugimendu bakoitzaren atalean inplikatuta dauden muskulu nagusien xehetasun anatomikoak aipatzen dira, hala nola muskuluaren jatorria, lotunea eta inerbazioa. 
Liburuak giltzadura bakoitzaren mugimenduak miatzeko prozedurak zehatz eta argi deskribatzen ditu, pazientearen eta fisioterapeutaren jarrerari, proba egiteko jarraibideei eta muskuluen indarraren mailaketari buruzko deskribapenarekin (Otik 5era bitartean graduatzen da muskuluen indarra). Muskulu bakoitza erreferentzia-zenbaki batekin identifikatzen du, bilaketetan berehala identifikatzeko lagungarria dena.

600 irudi inguru ditu, bai egitura anatomikoei buruzko informazioarekin, bai mugimendu bereziei buruzko xehetasunekin eta bai probak gauzatzeko pausoekin. Azken horietan geziak agertzen dira, terapeutak egin behar duen indarraren norabidea azaltzen dutenak eta pazienteak egin beharreko mugimenduak ulertzen laguntzen dutenak. Pazienteari eman beharreko jarraibideak ere aipatzen ditu, miaketa era egoki batean egiteko lagungarriak direnak. Egoera zehatzetan proba moldatzeko jarraibideak ere aipatzen dira, pazientearen beharrei egokitzeko baliagarriak direnak.

\section{Ondorioak}

Oro har, praktika klinikoan erabilgarrik diren gako ugari eskaintzen ditu liburuak era sinple eta argi baten emandako azalpenekin. Ikasleak eta profesionalak erraz laguntzen ditu muskuluen miaketarako probak ulertu eta aplikatzen, irudi sinple eta gezi lagungarriekin.

\section{Informazio gehiago}

https://web-

argitalpena.adm.ehu.es/listaproductos.asp?IdProducts=UCH00202338\&titulo=Daniels\%20eta\%20Wo rthingham-en\%20muskuluprobak.\%20Eskuzko\%20miaketarako\%20eta\%20funtzionamendua\%20balioesteko\%20teknikak

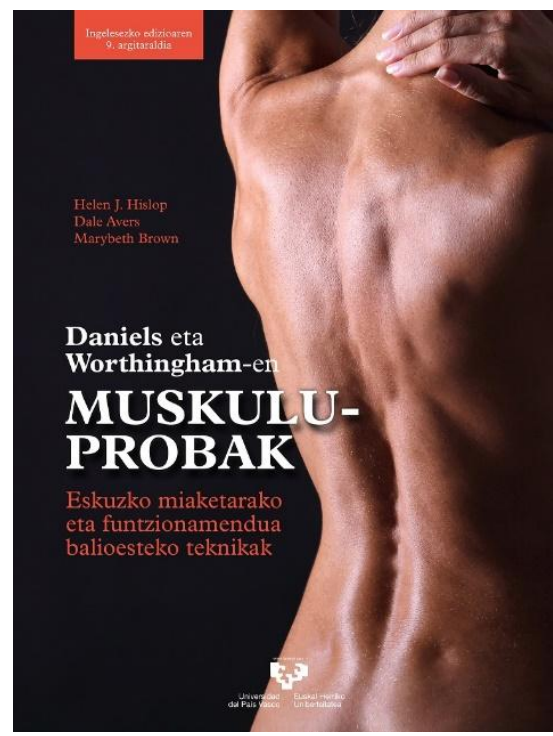

Izenburua: Daniels eta Worthingham-en muskulu-probak. Eskuzko miaketarako eta funtzionamendua balioesteko teknikak.

Autoreak: Hislop, Helen J.; Avers, Dale; Brown, Marybeth

Gaiak: fisioterapia, anatomia, fisiologia, osasuna.

Jakintza-arloa: fisioterapia

ISBN/ISSN: 978-84-1319-233-8

Argitalpen-urtea: 2020

Orrialdeak: 534 